\title{
Study on Association of Single Nucleotide Polymorphism of MC3R and MC4R Genes with Carcass and Meat Quality Traits in Chicken
}

\author{
Yan Wang ${ }^{1}$, Yi Su${ }^{1}$, Xiaosong Jiang ${ }^{2}$, Yiping $\mathrm{Liu}^{1}$, Xiaocheng $\mathrm{Li}^{3}$, \\ Zengrong Zhang ${ }^{1}$, Huarui $\mathrm{Du}^{3}$ and Qing $\mathrm{Zhu}^{1}$ \\ ${ }^{1}$ College of Animal Science and Technology, Sichuan Agricultural University, Ya'an, Sichuan, 625014, P.R. China \\ ${ }^{2}$ Sichuan Animal Science Academy, Chengdu, Sichuan, 610066, P.R. China \\ ${ }^{3}$ Sichuan Dahen Poultry Breeding Company, Chengdu, Sichuan 610066, P.R. China
}

\begin{abstract}
Body composition, fat deposition and meat quality are important traits in chickens. Melanocortin receptor (MCR) plays an important role in central melanocortin system (CMS) and muscle cells. The purpose of the present study was to analyze association of the $M C 3 R$ and the $M C 4 R$ genes with chicken carcass and meat quality traits. Using eight meat-type chicken populations constructed with 5 pure lines (developed from Chinese local breeds) and 3 crossbreeds (S01 $\times$ D $99, S 01 \times S 05, S$ $01 \times \mathrm{S} 10$ ), the association of 3 single nucleotide polymorphisms (SNP: $M C 3 R-\mathrm{A} 1424 \mathrm{G}, M C 4 R-\mathrm{G} 923 \mathrm{~T}$ and $M C 4 R-\mathrm{C} 944 \mathrm{~T}$ ) of $M C 3 R$ and $M C 4 R$ gene with carcass and meat quality traits was studied. The results showed as follows: (1) the $M C 3 R-A 1424$ $\mathrm{G}$ genotypes were significantly associated with most carcass traits except for semi-eviscerated percentage and leg muscle percentage (LMP), the MC4R-G923T genotypes were significantly associated with live weight, carcass weight, leg muscle weight (LMW) and LMP, and the MC4R-C944T genotypes were not significantly associated with most carcass traits except for LMW and LMP; (2) to meat quality, the $M C 3 R$-A1424G genotypes significantly affected muscle crude protein (GP) value, and the allele A had positive additive effects on slaughter traits. The $M C 4 R-\mathrm{G} 923 \mathrm{~T}$ and the $M C 4 R-C 944 \mathrm{~T}$ sites significantly affected muscle GP value and glutamic acid (Glu) value; (3) the haplotypes based on the 2 SNP of MC4R gene were also significantly associated with meat quality traits, but had no significant associations with carcass traits. The research built the base for further analysis on relation between genetic variation of $M C 3 R$ and $M C 4 R$ genes and the carcass and meat quality traits, and molecular marker's application in breeding.
\end{abstract}

Key words: carcass traits, chicken, $M C 3 R / M C 4 R$, meat quality, polymorphism

J. Poult. Sci., 46: 180-187, 2009

\section{Introduction}

Melanocortins are peptide hormones derived from proopiomelanocortin (POMC), they have an important role in regulating melanocyte pigmentation and energy homeostasis (Boswell and Takeuchi, 2005). They also play a part in a wide variety of physiological process including enhancement of learning and memory and thermoregulation (Walker et al., 1980). They mediate their effects through G-protein coupled receptors by stimulating adenylate cyclase (Gantz et al., 1993a; Boswell and Takeuchi, 2005). Now, all five melanocortin receptors (MCRs) have been isolated in chicken, each of the chicken $M C R$ subtypes has a different pattern of tissue expression and function. Recently, several studies in animal models suggest that $M C 3 R$ and $M C 4 R$ are essential in the regulation of feeding and energy homeostasis, respectively

Received: December 12, 2008, Accepted: March 3, 2009

Correspondence: Prof. Qing Zhu, College of Animal Science and Technology, Sichuan Agricultural University, Ya'an, Sichuan Province, 625014, China. (E-mail: zhuqing5959@163.com)
(Schwartz et al., 2000).

$M C 3 R$ is a 7-transmembrane G-protein coupled receptor which signals through the activation of adenylate cyclase (Gantz et al., 1993b). It is expressed in hypothalamic nuclei known to regulate energy homeostasis, exhibits a more restricted distribution than the $M C 4 R$ in the central nervous system (Roselli-Rehfuss et al., 1993), and has a dominant role in the inhibition of energy storage (Butler et al., 2000; Chen et al., 2000a). Some researchers reported that $M C 3 R^{-/}$homozygous for knockout mutations of the $M C 3 R$ gene had increased body fat with a reciprocal decrease in lean mass, not caused by increase food intake but arose from increased feed efficiency (Butler et al., 2000; Chen et al., 2000a). Chicken MC3R is a 325 amino acid protein, sharing $75.3-76.8 \%$ identity with the mammalian $M C 3 R$ (Takeuchi and Takahashi, 1999). Associations between polymorphism in $M C 3 R$ gene and obesity have been detected in humans (Civanova et al., 2006). It was reported that the $M C 3 R^{-/-}$mice were shown to have increased fat mass, reduced lean mass and had higher feed efficiency than wild-type littermates 
(Chen et al., 2000a, b).

The melanocortin-4 receptor $(M C 4 R)$ is also a 7transmembrane $\mathrm{G}$-protein coupled receptor whose ligand, $\alpha$-melanocyte-stimulating hormone ( $\alpha$-MSH) (Fan et al., 1997), is a posttranslational derivative of POMC. The gene encoding the $M C 4 R$ was initially localised by FISH to chromosome 18q21.3 (Gantz et al., 1993b) and was later sublocalised to 18q21.32 (Gerken et al., 1994). Recent studies demonstrated that $M C 4 R$ could mediate the control of both metabolic rate and food intake in mice (Huszar et al., 1997; Chen et al., 2000b). Selective blockage of the $M C 4 R$ in the brain stimulates food intake in rats (Kask et al., 1998), and also that $M C 4 R$ receptor signaling is involved in mediating leptin's inhibitory effect on food consumption (Kask et al., 1998). Chicken $M C 4 R$ is a 331 amino acid protein, sharing 86.5-88.1\% identity with mammalian sequence (Takeuchi and Takahashi, 1998) and it is expression in a wide variety of peripheral tissues such as gonads, spleen, adipose tissue, and skeletal muscle (Takeuchi and Takahashi, 1998). Huszar et al. (1997) have shown that absence of $M C 4 R$ produces an obesity syndrome in the agouti mouse. This consistent role in dietary regulation defines a novel function for the $M C 4 R$ in the regulation of metabolism and energy balance. In addition, several mutations including frameshift and nonsense ones were associated with dominantly inherited obesity in human (Vaisse, 1998; Yeo et al., 1998). Other missense mutations in humans also were identified (Gotoda, 1997; Hinney, 1999). Kim et al. (2000) used a candidate gene approach and reported that a missense mutation (Asp298Asn) in $M C 4 R$ was associated with fatness, growth and food intake traits in pigs.

So, in this study, we supposed that $M C 3 R$ and $M C 4 R$ genes were candidate genes for marker assisted selection (MAS) of fatness, growth traits in the chicken. The purposes of this study were to identify the polymorphisms in $M C 3 R$ and $M C 4 R$ genes using the single-strand conformation polymorphism (SSCP) method and to evaluate the genetic effects of these polymorphisms on carcass traits in chicken.

\section{Materials and Methods}

\section{Chicken Populations}

240 meat-type quality chickens from 8 populations (including 5 pure lines and 3 crossbreeds developed by Dahen Poultry Breeding Company and Sichuan Animal Science Academy) were studied. Populations S01, S05 and D99 have yellow partridge plumage with blue shanks and white skin. Population S03 has yellow plumage, yellow shank and white skin. S02 has black spotty feather, black skin and shank. Two-way cross S01 $\times$ S05 and S01 $\times$ D99 are commercial crossbreds. In the crossbred S01 $\times$ S10, pureline S10 is in process of breeding. All chickens were hatched on the same day, housed on the deep-litter bedding and moved to the growing pens at 7 weeks of age. Birds had access to feed (commercial corn-soybean diets meeting the National Research Council's requirements) and water ad libitum.

\section{Phenotypic Measurements}

Meat quality traits: Before slaughter of 90 days, blood was collected from these chickens. Carcass traits were measured at 90 days age, including body weight (BW) which was measured on live birds after $12 \mathrm{~h}$ with no access to feed. After slaughter also on day 90, the carcass traits including carcass weight $(\mathrm{CW})$, breast muscle weight (BMW), leg muscle weight (LMW), abdominal fat weight (AW) and subcutaneous fat thickness (SFT) were measured. The ratios of these traits to $\mathrm{CW}$ were calculated as semi-eviscerated percentage (SEP), leg muscle percentage (LMP). Subcutaneous fat thickness, skin and fat width were measured at the caudal spondyle. In addition, meat dry matter, crude protein, glutamic acid, intramuscular fat (IMF), inosinic acid (IMP), muscle fiber density (MFN) and muscle fiber diameter (MFD) were determined in the lab.

\section{Amplification and Population Genotyping}

Gene polymorphisms: Genomic DNA was isolated from blood samples by the phenol-chloroform method. Primer pairs (Table 1) were designed from the reference sequences of $M C 3 R$ and $M C 4 R$ in GenBank (Accession No: AB017137, AY545056) by Oligo 6.0 software. Primer pairs $M C 3 R-1$ and $M C 3 R-2$ were used to amplify the $204 \mathrm{bp}$ and $210 \mathrm{bp}$ fragments of the chicken $M C 3 R$ gene, while primer pairs $M C 4 R-1, M C 4 R-2, M C 4 R-3$ and $M C 4 R-4$ were used to amplify the fragments $(225 \mathrm{bp}, 268$ bp, $241 \mathrm{bp}$ and $274 \mathrm{bp}$ ) of the chicken $M C 4 R$ gene. The 10 $\mu \mathrm{L}$ Polymerarse Chain Reaction (PCR) volume included $0.8 \mu \mathrm{L}$ of genomic DNA $(100 \mathrm{ng} / \mu \mathrm{L}), 0.3 \mu \mathrm{L}$ of each primer $(10 \mathrm{pmol} / \mu \mathrm{L}), 5 \mu \mathrm{L}$ of $2 \times$ Master mix including $\mathrm{Mg}^{2+}$, dNTP and Taq DNA Polymerase (Beijing Tianwei Biology Technique Corporation). The PCR protocol was $94^{\circ} \mathrm{C}$ for 5 min followed by 35 cycles of $94^{\circ} \mathrm{C}$ for $45 \mathrm{~s}, 55^{\circ} \mathrm{C}$ for $35 \mathrm{~s}$, and $72^{\circ} \mathrm{C}$ for $45 \mathrm{~s}$ and a final extension at $72{ }^{\circ} \mathrm{C}$ for $6 \mathrm{~min}$. The PCR products of $M C 3 R$ and $M C$ $4 R$ were genotyped by gel electrophoresis as SSCP. The microliters of PCR product was mixed with $1 \mu \mathrm{L}$ denaturing buffer (98\% formamide, 0.09\% xylene cyanole FF, and $0.09 \%$ bromophenol blue) and then denatured at $99.9^{\circ} \mathrm{C}$ for $10 \mathrm{~min}$ followed by a rapid chill on ice for 5 min. The denatured PCR products were electrophoresed for $16 \mathrm{~h}$ at $8 \mathrm{~V} / \mathrm{cm}$ on $10 \%, 12 \%$ or $14 \%$ polyacrylamide gels. The DNA bands on the gel were stained by $0.1 \%$ $\mathrm{AgNO}_{3}$ for $30 \mathrm{~min}$, and then $3 \% \mathrm{Na}_{2} \mathrm{CO}_{3}$ for about 30 min. Individual SSCP banding pattern was determined under visible light. The PCR products of the different homozygous genotype were purified and sequenced by Shanghai Ying Jun Biology Technique Corporation.

\section{Statistical Analysis}

Data were analyzed with General Linear Model (GLM) procedures of SAS 8.0, and the genetic effects were analyzed by mixed procedure according to the following model: $\mathrm{Y}_{\mathrm{ijk}}=\mu+\mathrm{G}_{\mathrm{i}}+\mathrm{L}_{\mathrm{j}}+\mathrm{S}_{\mathrm{k}}+\mathrm{E}_{\mathrm{ijk}}$, where $\mathrm{Y}_{\mathrm{ijk}}=$ the dependent variable; $\mu=$ the population mean; $\mathrm{E}_{\mathrm{ijk}}=$ the random error; $G_{i}=$ the fixed effect associated with the 
Table 1. PCR forward (F) and reverse (R) primer pairs for the $M C 3 R$ and $M C 4 R$

\begin{tabular}{|c|c|c|c|}
\hline Primer pairs & Sequences & $\begin{array}{l}\text { Annealing } \\
\text { temperature }\end{array}$ & Amplification \\
\hline \multirow[t]{2}{*}{$M C 3 R-1$} & F: 5'-ATGCCCTCCTTTACCACAGTA-3' & 53.6 & $204 \mathrm{bp}$ \\
\hline & R: 5'-GGCGTGCAAACAGGAACA T-3' & & \\
\hline \multirow[t]{2}{*}{$M C 3 R-2$} & F: 5'-CCCGATGAATCCATACTGT-3' & 53.2 & $210 \mathrm{bp}$ \\
\hline & R: 5'-TTCCTCTGCTCCCACACAAAG-3' & & \\
\hline \multirow[t]{2}{*}{$M C 4 R-1$} & F: 5'-AGAAGTGAACTTAGGGGAGA-3' & $50.9^{\circ} \mathrm{C}$ & $225 \mathrm{bp}$ \\
\hline & R: 5'-TTGTGCTTTTCAGTTTGG-3' & & \\
\hline \multirow[t]{2}{*}{$M C 4 R-2$} & F: 5'-ACTACTGTCTGCCTTGGTGC-3' & $54.1^{\circ} \mathrm{C}$ & $268 \mathrm{bp}$ \\
\hline & R: 5'-AGGGGATACAAAGAGTTGTTC-3' & & \\
\hline \multirow[t]{2}{*}{$M C 4 R-3$} & F: 5'-TTCGCCCATGTACTT C-3' & $50.6^{\circ} \mathrm{C}$ & $241 \mathrm{bp}$ \\
\hline & R: 5'-CTGGAGGGCATAAAAGATAGT-3' & & \\
\hline \multirow[t]{2}{*}{$M C 4 R-4$} & F: 5'-CATGTTCATGATGGCTCG AAT-3' & $53.6^{\circ} \mathrm{C}$ & $274 \mathrm{bp}$ \\
\hline & R: 5'-CCGAAATGCATAGATAAGTGG-3' & & \\
\hline
\end{tabular}

genotype; $L_{j}=$ the fixed effect of chicken population; $S_{k}=$ the fixed effects of sex. The interaction $G_{i} \times L_{j}$ and $G_{i} \times S_{k}$ were not significant for any trait and therefore were not included in the model. The values were presented as least square means \pm standard error. The significant differences of least square means were tested with the Duncan test $(P$ $<0.01)$.

The data of some carcass traits did not conform to the normal distribution. LW, CW, LMW, AW and SFT were analyzed as the linear model with parameters estimated on the Square Root scale.

\section{Haplotype Construction}

Based on 2 single nucleotide polymorphisms (SNPs) in all of the 240 experimental birds, haplotypes were constructed with PHASE 2.0 programme (Stephens et al., 2001a), the function of which was to reconstruct haplotypes from the population data.

\section{Results}

\section{SNPs of the Chicken MC3R and MC4R Genes}

We scanned the entirely coding region of two candidate genes with six primer pairs in different populations using SSCP and sequencing methods. One novel variant was found at the $1424^{\text {th }}(\mathrm{A} \rightarrow \mathrm{G})$ nucleotide position of the $M C 3 R$ gene. Three novel variants were found at the $662^{\text {th }}$ $(\mathrm{G} \rightarrow \mathrm{C})$, the $923^{\text {th }}(\mathrm{G} \rightarrow \mathrm{T})$ and the $944^{\text {th }}(\mathrm{C} \rightarrow \mathrm{T})$ nucleotide position of the $M C 4 R$ gene. The A1424G of $M C 3 R$ was resulted in three different gel profiles (AA, AG and GG) (Fig 1A). The three genotypes (CC, CG, and GG) of $\mathrm{G} 662 \mathrm{C}$ in $M C 4 R$ could be well recognized by three different gel profiles (Fig 1B). Both G923T and C944T of $M C 4 R$ were located in the same fragment, which were resulted in six different gel profiles (CC, GG, TT, CT, GT and GC) (Fig 1C). All the mutations were verified sequencing. None of the three SNPs caused amino acid change.

Associations of SNP in MC3R and MC4R Genes with Carcass Traits

Because the frequency of $M C 4 R-\mathrm{G} 662 \mathrm{C}$ was low, so we thought it was no meaning to analyze the relationship between the mutation and the carcass traits for $\mathrm{G} 662 \mathrm{C}$ of $M C 4 R$. Thus, we omit the locus of $M C 4 R-G 662 C$. Association study between the $M C 3 R$ and $M C 4 R$ SNPs and carcass traits in the local chicken populations are summarized in Table 2a, b. In locus A1424G, the $M C 3 R$ genotypes were significantly associated with most carcass traits except for SEP and LMP. The allele A had positive additive effects on slaughter traits such as LW, CW and LMW $(P<0.01)$, and on BMW $(P<0.05)$, The AW and SFT of AA chickens were higher than that of GG $(P<$ $0.05)$, but were less than that of AG $(P>0.05)$, respectively. The allele A gene showed complete dominance effect. In locus G923T, LW, CW, LMW and LMP were significantly associated with $M C 4 R$ genotypes. The LW of GT chickens was notably higher than that of TT $(P<$ 0.05). There were no differences among other genotypes $(P>0.05)$. CW and LMP of GT genotypes were higher than that of TT $(P<0.05)$. Chickens with genotypes GT had higher LMW than GG (difference of $20.04 \mathrm{~g}$ ) and TT (difference of $30.57 \mathrm{~g}$ ), respectively $(P<0.01)$. No significant differences were detected for other carcass traits. The allele $G$ had a favorably positive effect on the LW, CW, LMW and LMP of chickens. In locus C944T, the genotypes were not significantly associated with most carcass traits except for LMW and LMP. CT chickens had higher LMW than TT chickens $(P<0.05)$, but there was no remarkable difference when comparing with $\mathrm{CC}(P>$ 0.05). The LMW of TT chickens was not different with that of CC chickens $(P>0.05)$. The LMP of CT chickens was higher than that of TT by $0.61 \%(P<0.05)$, and it's higher than that of $\mathrm{CC}$ by $0.36 \%$. There was no difference between $\mathrm{CT}$ and $\mathrm{CC}$ chickens $(P>0.05)$. No differences were observed for other carcass traits. The $\mathrm{C}$ allele had a favorably positive effect on traits LMW and LMP.

Associations of SNP in MC3R and MC4R Genes with Meat Quality Traits

The associations of $M C 3 R$-A1424G genotypes, $M C 4$ $R$-G923T and $M C 4 R$-C944T with meat quality traits in chickens were analyzed, and the least square means of three genotypes were showed in Table 3 and Table $4 a, b$. 


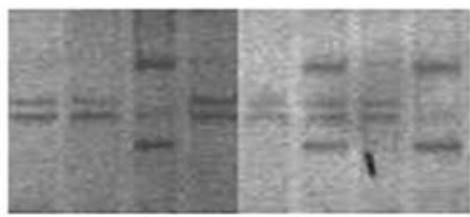

AA AA GG AA AA AG AA GG

A

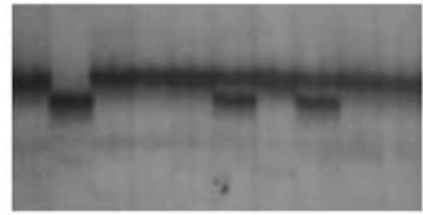

CC GG CC CC CC CG CC CG CC CC

B

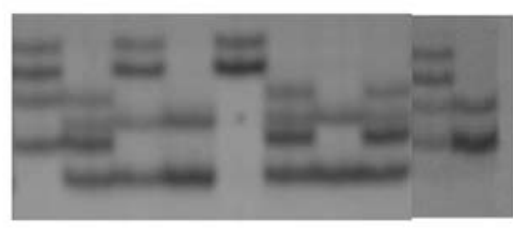

GC CT GT TT GG CT TT CT GC CC

C

Fig. 1. Mutation detection by using the SSCP method. A) The electrophoresis profiles of the joint SNP1 of $M C 3 R$. Three profiles (AA, AG and GG) were observed in the gel picture. B) The electrophoresis profiles of SNP1 genotypes $\mathrm{CC}, \mathrm{CG}$, and $\mathrm{GG}$ of $M C 4 R$. C) The electrophoresis profiles of the joint SNP2 and SNP3 genotypes of $M C 4$ $R$. Six profiles (CC, GG, TT, CT, GT and GC) were observed in the gel picture.

Table 2 a. Effect of MC3R-SNP1 on the carcass traits (least square mean and standard error)

\begin{tabular}{|c|c|c|c|}
\hline \multirow[b]{2}{*}{ Trait $^{1}$} & \multicolumn{3}{|c|}{ SNP1 (A1424G) } \\
\hline & AG (84) & AA (106) & GG (35) \\
\hline LW (g) & $1867.45^{\mathrm{aA}} \pm 23.05$ & $1848.15^{\mathrm{aAB}} \pm 25.7$ & $1740.86^{\mathrm{bB}} \pm 39.39$ \\
\hline CW (g) & $1664.62^{\mathrm{aA}} \pm 21.58$ & $1640.48^{\mathrm{aAB}} \pm 24.1$ & $1541.43^{\mathrm{bB}} \pm 36.88$ \\
\hline BMW (g) & $200.32^{\mathrm{a}} \pm 3.56$ & $197.38^{\mathrm{ab}} \pm 3.97$ & $184.75^{b} \pm 6.09$ \\
\hline LMW (g) & $290.39^{\mathrm{aA}} \pm 5.42$ & $289.78^{\mathrm{aA}} \pm 4.87$ & $262.88^{\mathrm{bB}} \pm 8.31$ \\
\hline $\mathrm{AW}(\mathrm{g})$ & $41.41^{\mathrm{a}} \pm 2.23$ & $39.80^{\mathrm{ab}} \pm 2.00$ & $35.97^{\mathrm{b}} \pm 3.41$ \\
\hline SFT (mm) & $3.85^{\mathrm{a}} \pm 0.09$ & $3.80^{\mathrm{ab}} \pm 0.08$ & $3.53^{\mathrm{b}} \pm 0.14$ \\
\hline$\%$ SEP & $92.94^{\mathrm{a}} \pm 0.24$ & $92.88^{\mathrm{a}} \quad \pm 0.27$ & $92.77^{\mathrm{a}} \pm 0.41$ \\
\hline$\%$ LMP & $17.59^{\mathrm{a}} \pm 0.16$ & $17.22^{\mathrm{a}} \quad \pm 0.14$ & $17.10^{\mathrm{a}} \pm 0.24$ \\
\hline
\end{tabular}

b. Effect of $M C 4 R-\mathrm{SNP} 2$ and $M C 4 R-\mathrm{SNP} 3$ on the carcass traits (least square mean and standard error)

\begin{tabular}{|c|c|c|c|c|c|c|c|}
\hline \multirow{3}{*}{$\frac{\text { Traits }^{1}}{\text { LW (g) }}$} & \multicolumn{4}{|c|}{ SNP2 (G923T) } & \multicolumn{3}{|c|}{ SNP3 (C944T) } \\
\hline & \multirow{2}{*}{$\frac{\text { GT (109) }}{1874.40^{\mathrm{a}} \pm 22.1}$} & \multicolumn{2}{|c|}{ GG (93) } & \multirow{2}{*}{$\frac{\text { TT (23) }}{1772.61^{\mathrm{b}} \pm 48.6}$} & \multirow{2}{*}{$\begin{array}{c}\text { CT (118) } \\
1849.92^{\mathrm{a}} \pm 21.4\end{array}$} & \multirow{2}{*}{$\frac{\mathrm{CC}(74)}{1848.45^{\mathrm{a}} \pm 27.1}$} & \multirow{2}{*}{$\begin{array}{c}\text { TT (33) } \\
1789.39^{\mathrm{a}} \pm 41.6\end{array}$} \\
\hline & & $1817.69^{\mathrm{ab}}$ & \pm 238 & & & & \\
\hline CW (g) & $1663.76^{\mathrm{a}} \pm 20.7$ & $1617.20^{\mathrm{ab}}$ & \pm 224 & $1584.78^{\mathrm{b}} \pm 45.6$ & $1644.93^{\mathrm{a}} \pm 25.3$ & $1641.10^{\mathrm{a}} \pm 20.0$ & $1600.76^{a} \pm 38.9$ \\
\hline BMW (g) & $201.65^{\mathrm{a}} \pm 0.13$ & $193.77^{\mathrm{a}}$ & \pm 0.28 & $191.87^{\mathrm{a}} \pm 0.14$ & $198.99^{\mathrm{a}} \pm 0.12$ & $194.56^{\mathrm{a}} \pm 0.24$ & $194.31^{\mathrm{a}} \pm 0.15$ \\
\hline LMW (g) & $295.58^{\mathrm{aA}} \pm 4.66$ & $279.54^{\mathrm{abAB}}$ & \pm 5.0 & $265.01^{\mathrm{bB}} \pm 10.3$ & $290.76^{a} \pm 4.53$ & $284.64^{\mathrm{ab}} \pm 5.74$ & $270.86^{\mathrm{b}} \pm 8.81$ \\
\hline $\mathrm{AW}(\mathrm{g})$ & $40.18^{\mathrm{a}} \pm 1.93$ & $39.68^{\mathrm{a}}$ & \pm 2.08 & $38.52^{\mathrm{a}} \pm 4.23$ & $40.15^{\mathrm{a}} \pm 3.62$ & $39.94^{\mathrm{a}} \pm 2.36$ & $39.62^{\mathrm{a}} \pm 1.86$ \\
\hline SFT $(\mathrm{mm})$ & $3.88^{\mathrm{a}} \pm 0.09$ & $3.85^{\mathrm{a}}$ & \pm 0.08 & $3.68^{\mathrm{a}} \pm 0.18$ & $3.87^{\mathrm{a}} \pm 0.10$ & $3.74^{\mathrm{a}} \pm 0.08$ & $3.73^{\mathrm{a}} \pm 0.15$ \\
\hline$\%$ SEP & $93.15^{\mathrm{a}} \pm 0.23$ & $92.73^{\mathrm{a}}$ & \pm 0.25 & $92.28^{\mathrm{a}} \pm 0.51$ & $93.08^{\mathrm{a}} \pm 0.22$ & $92.81^{\mathrm{a}} \pm 0.28$ & $92.36^{\mathrm{a}} \pm 0.43$ \\
\hline$\%$ LMP & $17.62^{\mathrm{a}} \pm 0.14$ & $17.15^{\mathrm{ab}}$ & \pm 0.15 & $16.78^{\mathrm{b}} \pm 0.30$ & $17.55^{\mathrm{a}} \pm 0.13$ & $17.19^{\mathrm{ab}} \pm 0.17$ & $16.94^{\mathrm{b}} \pm 0.26$ \\
\hline
\end{tabular}

Note: The least square means within a row with different super scripts differ significantly; the lower case letters show the level of 0.01 ; the capital letters show the level of 0.05 . The numbers in the brackets are the number of individual chickens carrying the respective genotypes.

${ }^{1} \mathrm{LW}=$ live body weight; $\mathrm{CW}=$ carcass weight; $\mathrm{BMW}=$ breast muscle weight; $\mathrm{LMW}=$ leg muscle weight; $\mathrm{AW}=\mathrm{abdominal}$ weight; $\mathrm{SFT}=$ subcutaneous fat thickness; $\mathrm{SEP}=$ semi-eviscerated percentage; LMP $=$ leg muscle percentage; \% proportion of SEP and LMP to CW. 
Table 3. Effect of $M C 3 R-1424$ genotypes in SNP1 on the meat quality traits (least square mean and standard error)

\begin{tabular}{|c|c|c|c|c|c|c|}
\hline Meat traits ${ }^{1}$ & \multicolumn{2}{|c|}{ AA (27) } & AG (32) & GG (23) & $\mathrm{AE}$ & $\mathrm{DE}$ \\
\hline Matter (\%) & $88.74^{\mathrm{a}}$ & \pm 1.80 & $91.64^{\mathrm{a}} \pm 1.62$ & $91.54^{\mathrm{a}} \pm 2.26$ & -1.4 & 0.75 \\
\hline GP $(\%)$ & $83.94^{\mathrm{ABab}}$ & \pm .426 & $83.07^{\mathrm{Bb}} \pm 0.384$ & $84.37^{\mathrm{Aa}} \pm 0.536$ & -0.215 & -0.5425 \\
\hline $\operatorname{IMF}(\%)$ & $5.07^{\mathrm{Aab}}$ & \pm 0.351 & $5.49^{\mathrm{Aa}} \pm 0.316$ & $4.50^{\mathrm{Ab}} \pm 0.441$ & -0.21 & -0.39 \\
\hline $\operatorname{IMP}(\%)$ & $1.50^{\mathrm{a}}$ & \pm 0.032 & $1.46^{\mathrm{a}} \pm 0.029$ & $1.50^{\mathrm{a}} \pm 0.041$ & 0 & -0.02 \\
\hline Glu (mg/g) & $5.454^{\mathrm{a}}$ & \pm 0.122 & $5.153^{\mathrm{a}} \pm 0.110$ & $5.289^{\mathrm{a}} \pm 0.154$ & 0.083 & -0.109 \\
\hline $\operatorname{MFN}\left(\mathrm{n} / \mathrm{mm}^{2}\right)$ & $879.71^{\mathrm{a}}$ & \pm 46.85 & $908.25^{\mathrm{a}} \pm 44.03$ & $836.86^{\mathrm{a}} \pm 61.21$ & 21.425 & 24.98 \\
\hline MFD (um) & $34.68^{\mathrm{a}}$ & \pm 0.89 & $34.88^{\mathrm{a}} \pm 0.83$ & $35.88^{\mathrm{a}} \pm 1.16$ & -0.6 & -0.2 \\
\hline
\end{tabular}

Note: Values with different letters with the same row differ significantly; the lowercase letters show the level of 0.01 ; the capital letters show the level of 0.05 .

${ }^{1} \mathrm{IMF}=$ intramuscular fat; IMP=inosinic acid; MFN= muscle fiber density; $\mathrm{MFD}=$ muscle fiber diameter; $\mathrm{DM}=$ dry matter; $\mathrm{GP}=$ crude protein; $\mathrm{Glu}=$ glutamic acid; $\mathrm{AD}=$ addictive effects; $\mathrm{DE}=$ dominance effects.

Table 4. a. Effect of MC4R-SNP2 on the meat quality traits (least square mean and standard error)

\begin{tabular}{|c|c|c|c|c|c|c|c|c|}
\hline \multirow{3}{*}{$\begin{array}{l}\text { Meat traits }{ }^{1} \\
\text { Matter (\%) }\end{array}$} & \multicolumn{8}{|c|}{ SNP2 (G923T) } \\
\hline & \multicolumn{2}{|c|}{ GG (29) } & \multicolumn{2}{|c|}{ GT (43) } & \multicolumn{2}{|c|}{ TT (8) } & \multirow{2}{*}{$\begin{array}{c}\mathrm{AE} \\
-2.655\end{array}$} & \multirow{2}{*}{$\begin{array}{l}\mathrm{DE} \\
0.3325\end{array}$} \\
\hline & $88.32^{\mathrm{a}}$ & \pm 1.77 & $91.64^{\mathrm{a}}$ & \pm 1.42 & $93.63^{\mathrm{a}}$ & \pm 3.40 & & \\
\hline GP $(\%)$ & $83.20^{\mathrm{B}}$ & \pm 0.432 & $83.67^{\mathrm{Bb}}$ & \pm 0.345 & $85.26^{\mathrm{B}}$ & \pm 0.83 & -1.03 & -0.28 \\
\hline $\operatorname{IMF}(\%)$ & $5.13^{\mathrm{a}}$ & \pm 0.351 & $5.12^{\mathrm{a}}$ & \pm 0.281 & $5.13^{\mathrm{a}}$ & \pm 0.672 & 0.002 & -0.006 \\
\hline $\operatorname{IMP}(\mathrm{mg} / \mathrm{g})$ & $1.479^{\mathrm{a}}$ & \pm 0.032 & $1.486^{\mathrm{a}}$ & \pm 0.025 & $1.489^{\mathrm{a}}$ & \pm 0.061 & -0.005 & 0.001 \\
\hline Glu (mg/g) & $4.995^{\mathrm{B}}$ & \pm 0.115 & $5.539^{\mathrm{A}}$ & $\mathrm{a} \pm 0.092$ & $4.976^{\mathrm{B}}$ & \pm 0.221 & 0.010 & 0.278 \\
\hline MFN $(\%)$ & $926.4^{\mathrm{a}}$ & \pm 46.33 & $836.56^{\mathrm{a}}$ & \pm 36.36 & $968.6^{\mathrm{a}}$ & \pm 85.57 & -21.135 & -55.49 \\
\hline MFD (um) & $34.78^{\mathrm{a}}$ & \pm 0.90 & $35.50^{\mathrm{a}}$ & \pm 0.70 & $33.50^{\mathrm{a}}$ & \pm 1.65 & 0.64 & 0.68 \\
\hline
\end{tabular}

b. Effect of MC4R-SNP3 on the meat quality traits (least square mean and standard error)

\begin{tabular}{|c|c|c|c|c|c|}
\hline \multirow{2}{*}{ Meat traits ${ }^{1}$} & \multicolumn{5}{|c|}{ SNP3 (C944T) } \\
\hline & $\mathrm{CC}(21)$ & CT (44) & TT (15) & $\mathrm{AE}$ & $\mathrm{DE}$ \\
\hline Matter (\%) & $87.42^{\mathrm{Ab}} \pm 2.05$ & $91.39^{\mathrm{Aab}} \pm 1.39$ & $92.95^{\mathrm{Aa}} \pm 2.58$ & -2.765 & 0.6025 \\
\hline GP $(\%)$ & $83.75^{\mathrm{Bb}} \pm 0.497$ & $83.08^{\mathrm{Bb} *} \pm 0.338$ & $85.23^{\mathrm{Aa} *} \pm 0.626$ & -0.74 & -0.705 \\
\hline $\operatorname{IMF}(\%)$ & $4.85^{\mathrm{a}} \pm 0.402$ & $5.19^{\mathrm{a}} \pm 0.273$ & $5.30^{\mathrm{a}} \quad \pm 0.506$ & -0.225 & 0.0575 \\
\hline $\operatorname{IMP}(\mathrm{mg} / \mathrm{g})$ & $1.509^{\mathrm{a}} \pm 0.037$ & $1.455^{\mathrm{a}} \pm 0.025$ & $1.533^{\mathrm{a}} \pm 0.047$ & -0.012 & -0.033 \\
\hline Glu (mg/g) & $5.002^{\mathrm{Bb}} \pm 0.138$ & $5.463^{\mathrm{Aa}} \pm 0.094$ & $5.163^{\mathrm{AB}} \pm 0.173$ & -0.081 & 0.190 \\
\hline MFN $(\%)$ & $909.42^{\mathrm{a}} \pm 55.48$ & $860.09^{\mathrm{a}} \quad \pm 37.09$ & $909.41^{\mathrm{a}} \quad \pm 70.57$ & 0.005 & -24.66 \\
\hline MFD (um) & $34.54^{\mathrm{a}} \quad \pm 1.04$ & $35.64^{\mathrm{a}} \quad \pm 0.70$ & $33.91^{\mathrm{a}} \pm 1.33$ & 0.315 & 0.71 \\
\hline
\end{tabular}

Note: Values with different letters with the same row differ significantly; the lowercase letters show the level of 0.01 ; the capital letters show the level of 0.05 ; the mark $* *$ and $*$ show very significant difference between the two values at level of 0.01 .

${ }^{1} \mathrm{IMF}=$ intramuscular fat; IMP $=$ inosinic acid; $\mathrm{MFN}=$ muscle fiber density; $\mathrm{MFD}=$ muscle fiber diameter; DM $=$ dry matter; $\mathrm{GP}=$ crude protein; $\mathrm{Glu}=$ glutamic acid; $\mathrm{AD}=$ addictive effects; $\mathrm{DE}=$ dominance effects.

In locus $M C 3 R$-A1424G, GP was significantly associated with $M C 3 R$ genotypes. The GP of GG was notably higher than that of AG and AA $(P<0.05)$. No differences were observed for other meat quality traits. In locus $M C 4 R-G$ 923T, GP and Glu were significantly associated with $M C$ $4 R$ genotypes. The GP of TT was notable higher than that of GG and GT $(P<0.05)$, but there were no differences among the latter genotypes $(P>0.05)$. GG chicken had lower glutamic acid than GT chickens $(P<0.05)$, but there was no remarkable difference as compared with TT $(P<0.05)$. No differences were observed for other meat quality traits. In locus $M C 4 R$-C944T, differences among $M C 4 R$ genotypes were significant for trait Matter, GP and Glu. TT chickens had higher Matter than CC chickens ( $P$ $<0.01)$, but there was no remarkable difference as compared with CT $(P>0.01)$. For GP trait, TT chickens had higher GP than $\mathrm{CT}$ and $\mathrm{CC}$ chickens by $2.15 \%(P<0.01)$ and $1.48 \%(P<0.05)$ respectively. For Glu trait, CT chickens had higher Glu than CC chickens $(P<0.05)$. No significant differences were detected for other meat quality traits. 
Table 5. Associations between diplotypes and the chicken meat quality traits ${ }^{1,2,3}$

\begin{tabular}{ccccccccc}
\hline \hline \multirow{2}{*}{ Haplotype } & & \multicolumn{3}{c}{ Traits } \\
& DM (\%) & Protein* & IMP (\%) & Glu (mg/g) & MFN* & MFD & Fat* & Ash \\
\hline H1H1 & $87.42 \pm 2.09$ & $83.75 \pm 0.76$ & $1.51 \pm 0.04$ & $5.00 \pm 0.21$ & $909.42 \pm 54.45$ & $0.03 \pm 0.001$ & $4.85 \pm 0.39$ & $4.31 \pm 0.05$ \\
H1H2 & $90.39 \pm 3.91$ & $\underline{80.27 \pm 1.42}$ & $1.37 \pm 0.08$ & $5.14 \pm 0.39$ & $\mathbf{1 0 6 8 . 4 9} \pm \mathbf{1 0 6 . 1 4}$ & $0.04 \pm 0.002$ & $\underline{6.71 \pm 0.73}$ & $4.27 \pm 0.09$ \\
H1H3 & $91.54 \pm 1.56$ & $83.52 \pm 0.56$ & $1.47 \pm 0.03$ & $5.51 \pm 0.16$ & $831.93 \pm 39.02$ & $0.04 \pm 0.001$ & $4.96 \pm 0.29$ & $4.32 \pm 0.04$ \\
H2H2 & $91.68 \pm 6.77$ & $\mathbf{8 6 . 2 6} \pm \mathbf{2 . 4 6}$ & $1.49 \pm 0.13$ & $4.48 \pm 0.68$ & $\underline{732.42 \pm 167.82}$ & $0.04 \pm 0.003$ & $\mathbf{3 . 3 3} \pm \mathbf{1 . 2 6} \mathbf{1}^{1}$ & $4.33 \pm 0.16$ \\
H2H3 & $92.37 \pm 4.28$ & $84.76 \pm 1.56$ & $1.62 \pm 0.08$ & $5.73 \pm 0.43$ & $879.38 \pm 118.67$ & $0.03 \pm 0.002$ & $6.36 \pm 0.79$ & $4.29 \pm 0.10$ \\
H3H3 & $93.63 \pm 3.38$ & $85.26 \pm 1.23$ & $1.49 \pm 0.07$ & $4.98 \pm 0.34$ & $968.67 \pm 83.91$ & $0.03 \pm 0.002$ & $5.13 \pm 0.63$ & $4.47 \pm 0.08$ \\
\hline
\end{tabular}

${ }^{1}$ Bold represents the advantageous diplotypes.

${ }^{2}$ Least squares means \pm standard error means.

${ }^{3}$ Underline represents the negative diplotypes. $* P \leq 0.05$.

$\mathrm{IMP}=$ intramuscular fat percent; $\mathrm{MFN}=$ muscle fiber density; $\mathrm{MFD}=$ muscle fiber diameter; $\mathrm{DM}=$ dry matter; Glu $=\mathrm{glutamic}$ acid.

\section{Construction of Haplotypes and their Associations with Chicken Carcass/Meat Quality Traits}

In this study, we estimated haplotypes from two SNP genotypes of $M C 4 R$ gene. These results showed that a total of 4 haplotypes were found in the $M C 4 R$ gene. These haplotype contained two major ones of H1 ("GC", $59.11 \%$ ) and $\mathrm{H} 4$ ("TT", $34.43 \%$ ), one minor ones of $\mathrm{H} 2$ ("GT", 6.45\%), as well as one rare ones (H3) with frequencies lower than $1 \%$. The mixed model analysis indicated that there were no significant associations of haplotypes with carcass traits, but there were significant associations of haplotypes with meat quality traits (Table 5). Haplotypes were associated with protein, MFN and Fat $(P<0.05)$. Significantly and suggestively dominant effects of $\mathrm{H} 1 \mathrm{H} 2$ haplotype were observed for MFN and the $\mathrm{H} 2 \mathrm{H} 2$ was dominant for Protein and Fat. Results also betrayed that $\mathrm{H} 2 \mathrm{H} 2$ haplotype had a negative effect on MFN, while the H1H2 diplotype had a positive effect on Fat.

\section{Discussion}

At present, numerous researches have revealed that there is a correlation between the $M C 3 R / M C 4 R$ genes and the obesity. In vitro studies conducted by Feng et al. (2005) showed that double homozygosity for $M C 3 R$ sequence variants $\mathrm{C} 17 \mathrm{~A}$ and $\mathrm{G} 214 \mathrm{~A}$ affected melanocortin receptor function. In addition, Santoro et al. (2007) also found that the MC3R C17A and G241A variants affect the childhood obesity. Moreover, Lee et al. (2002) reported that the T548A mutation of $M C 3 R$ gene associated with obesity in human. However, there is no report the SNP of chicken $M C 3 R$ on NCBI (http://www. ncbi.nlm.nih.gov/sites/entrez), we found an A/G mutation at base position 1424 in this study.

Yeo et al. and Vaisse et al. (1998) reported the first MC $4 R$ mutation in humans in 1998. Dubern et al. (2001) searched for the mutations in MC4R, AGRP, and $\alpha$-MSH genes in 63 severely obese children by direct sequencing of the MC4R encoding sequence and SSCP analysis of AGRP and $\alpha$-MSH genes. The results showed that expression of the obese phenotype was variable in mutation- positive family members. And they made a conclusion that the $M C 4 R$ mutations may be a non-negligible cause of severe obesity in children with variable expression and penetrance. Rosmond et al. (2001) studied the missense mutation of the $M C 4 R$ gene in human. Their findings suggested that the missense mutation could contribute to the variability in body mass, abdominal fat distribution, leptin concentrations and diurnal cortisol levels. In poultry, Huo et al. (2006) found that there was a G/T mutation at base position 315 , and there was a significant association between the genotypes and body weight, carcass weight and breast muscle weight. At present, there were 9 SNP of chicken $M C 4 R$ had been reported, their SNP ID was rs15115106, rs15115105, rs15115104, rs 15115103, rs15115102, rs14202566, rs14202565, rs 14202564 and rs 14202563 on BCBI. But in our study, we only found two SNP in chicken MC4R gene, one was a G/ $\mathrm{T}$ mutation at base position 923 , the other was a $\mathrm{C} / \mathrm{T}$ mutation at base position 944 . The reasons may be as follows: 1) we only scanned the complete coding region of chicken $M C 4 R$ gene instead of whole sequence; 2) different chicken populations with various domestication background.

Interestingly, in this study, the one SNP of chicken $M C$ $3 R$ and two SNPs of chicken $M C 4 R$ were no lead to amino acid changes, but the mutation had effect on carcass traits. Although the nucleotide substitution, or the frame-shift mutation of the genetic mutation may could change the amino sequence of the target gene, or terminated without produce peptide synthesis of complete peptide chains. But because of the genetic code with degeneracy, so some alkali gene replacement may not cause amino acid sequence of change. In this study, our results were synonymous variations, with code base sequence changed but amino acid sequence had no changed, the reason why the mutation with same amino acid sequence had effect on carcass traits still unclear. Li et al. (2008) found that the synonymous mutations of $M C 4 R$ in pigeon had great effect on some characters.

In addition, in our study, we found that there was significant difference between populations about carcass 
traits (not shown data). Due to the aim of this present study was to analyze association of the SNP genotypes of $M C 3 R$ and the $M C 4 R$ genes with chicken carcass and meat quality traits, so we omit the result of the comparison within and between populations about carcass traits. The results of association analysis between single SNP of chicken $M C 3 R$ and $M C 4 R$ genes and carcass traits approved our conjecture that the genotypes of these SNPs were significantly or great significantly associated with chicken carcass traits. This result was identical with adipose differentiation-related protein's function that controlling metabolism of triglyceride and in the control of ingestive behavior and energy homeostasis.

Furthermore, as association analysis between single SNP and traits did not take the interactions between non-alleles into account, and it did not consider the linkage disequilibrium between the SNPs, we took use of haplotype which was composed of several SNPs in a chromosome to solve this problem. Haplotypes were constructed with the 2 SNPs and were used to analyse the associations of diplotypes combinations with carcass and meat quality traits. The $\mathrm{H} 1 \mathrm{H} 2$ and $\mathrm{H} 2 \mathrm{H} 2$ diplotypes were found to be associated with higher MFN and Protein than other diplotypes respectively, and the frequency of $\mathrm{H} 1$ (GC) was 59.11\% in all experimental chickens. Therefore, $\mathrm{H} 1$ may be the most disadvantageous haplotype for fat trait. Current data showed that associations of haplotypes with carcass and meat quality traits were more accurate than those of single SNP. This result implied that there was an interaction between different SNPs, and that the haplotypes generally provide more information content (heterozygosity) than one SNP did (Stephens et al., 2001a). Thus, it was observed that both haplotype diversity and the method of SNP selection based on maximizing haplotype diversity were preferred to single SNP (Huang et al., 2003; Zhang et al., 2004).

In summary, commercial breeding programs of broiler chickens have became more and more complex, so it would be wise for us to use molecular MAS method to improve growth rate, increase breast muscle yield, decrease abdominal fat, at the same time to maintain good development and overall fitness. The results of current research indicated that 3 SNP markers were associated with carcass traits and meat quality traits, so we could draw the conclusion that $M C 3 R$ and $M C 4 R$ genes played an important role in the regulation of fat deposition and growth in chickens, in other words, the $M C 3 R$ and $M C 4 R$ genes manifested a great potential for use in molecular MAS programs to control carcass traits and meat quality traits.

\section{Conclusion}

By using GLM analysis, we found that MC3R-A1424G site very significantly affected $\mathrm{LW}, \mathrm{CW}$ and LMW and significantly affected BMW, AW, SFT and GP value $(P<$ $0.05)$ and not affected $\operatorname{IMP}(P>0.05)$. The allele $\mathrm{A}$ had positive additive effects on slaughter traits, and the geno- type AA had high body fat content. MC4R-G923T site significantly influenced muscle GP value and glutamic acid (Glu) value. The GT heterozygote genotype had high LW, LMW, LMP and high Glu value. MC4R-C944 T site significantly affected LMW, LMP, GP value and Glu. The CT heterozygote genotype had high LMW, LMP and high Glu value. We also found that the allele frequencies of $\mathrm{G}$ and $\mathrm{C}$ were higher than those of allele $\mathrm{T}$ in each chicken population.

The role of $M C 4 R$ and $M C 3 R$ in meat quality and carcass related traits suggested it might be important genetic markers for the related traits of chicken. It may be related with other obesity-related traits. For the effect of $M C 4 R$ and $M C 3 R$ variants, we should enlarge the sample size for further analysis.

\section{Acknowledgments}

This work was financially supported by the Provincial Eleventh 5-year Programs on Animal Breeding of Sichuan Province (No. 2006YZGG-19, 2006YZGG-25), the National 863 Project of China (No. 2008AA101001) and the Chinese national key technologies R \& D programme (Grant No: 2008BADB2B01).

\section{References}

Boswell T and Takeuchi S. Recent developments in our understanding of the avian melanocortin system: its involvement in the regulation of pigmentation and energy homeostasis. Peptides, 26: 1733-1742. 2005.

Butler AA, Kesterson RA, Khong K, Cullen MJ, Pelleymounter MA, Dekoning J, Baetscher $M$ and Cone RD. A unique metabolic syndrome causes obesity in the melanocortin-3 receptor-deficient mouse. Endocrinology, 141: 3518-3521. 2000.

Chen AS, Marsh DJ, Trumbauer ME, Frazier EG., Guan XM, Yu H, Rosenblum CI, Vongs A, Feng Y, Cao L, Metzger JM, Strack AM, Camacho RE, Mellin TN, Nunes CN, Min W, Fisher J, Gopal-Truter S, MacIntyre DE, Chen HY and Vander LH. Inactivation of the mouse melanocortin-3 receptor results in increased fat mass and reduced lean body mass. Nature Genetics, 26: 97-102. 2000a.

Chen AS, Metzger JM, Trumbauer ME, Guan XM, Yu H, Frazier EG, Marsh DJ, Forrest MJ, Gopal-Truter S, Fisher J, Camacho RE, Strack AM, Mellin TN, MacIntyre DE, Chen HY and Vander Ploeg LH. Role of the melanocortin4 receptor in metabolic rate and food intake in mice. Transgenic Research, 9: 145-154. 2000b.

Civanova K, Knoll A, Rohrer GA and Cepica S. Linkage mapping of the $M C 3 R$ gene to porcine chromosome 17. Animal Genetics, 35: 467-469. 2006.

Dubern B, Clement K and Pelloux V. Mutational analysis of melanocortin-4 receptor, agouti-related protein, and alphamelanocyte-stimulating hormone genes in severely obese children. Journal of Pediatrics, 139: 204-209. 2001.

Fan W, Boston BA, Kesterson RA, Hruby VJ and Cone RD. Role of melanocortigenic neurons in feeding and the agouti obesity syndrome. Nature, 385: 165-168. 1997.

Feng N, Young SF and Aguilera G. Co-occurrence of two partially inactivating polymorphisms of MC3R is associated with pediatric-onset obesity. Diabetes, 54: 2663-2667. 2005. 
Gantz I, Konda Y, Tashiro T, Shimoto Y, Miwa H, Munzert G, Watson SJ, Delvalle J and Yamada T. Molecular cloning of a novel melanocortin receptor. Journal of Biological Chemistry, 268: 8246-8250. 1993a.

Gantz I, Mjwa H, Konda Y, Shimoto Y, Tashiro T, Watson SJ, Delvalle $\mathrm{J}$ and Yamada T. Molecular cloning, expression, and gene localization of a fourth melanocortin receptor. Journal of Biological Chemistry, 268: 15174-15179. 1993b.

Gerken S, Fish K and Uyar D. Integration of 28 STSs into the physical map of human chromosome 18. Genome, 24: 612613. 1994.

Gotoda T. Molecular screening of the human melanocortin-4 receptor gene: identification of a missense variant showing no association with obesity, plasma glucose, or insulin. Diabetologia, 40: 976-979. 1997.

Hinney A. Several mutations in the melanocortin-4 receptor gene including a nonsense and a frameshift mutation associated with dominantly inherited obesity in humans. Journal of Clinical Endocrinology and Metabolism, 84: 1483-1486. 1999.

Huang QQ, Fu YX and Boerwinkle E. Comparison of strategies for selecting single nucleotide polymorphisms for case/control association studies. Human Genetics, 113: 253-257. 2003.

Huo MD, Wang SZ and Li H. Study on the correlation between SNP of $M C 4 R$ and body weight and fat traits in chicken. Journal of Northeast Agricultural University, 37(2): 184189. 2006.

Huszar D, Lynch CA, Fairchild-Huntress V, Dunmore JH, Fang Q, Berkemeier LR, Gu W, Kesterson RA, Boston BA, Cone RD, Smith FJ, Campfield LA, Burn P and Lee F. Targeted disruption of the melanocortin 4 receptor results on obesity in mice. Cell, 88: 131-141. 1997.

Kask A, Rago L, Wikberg JES and Schioth HB. Evidence for involvement of the melanocortin $M C 4 R$ receptor in the effect of leptin on food intake and body weight. European Journal of Pharmacology, 360: 15-19. 1998.

Kim KS, Larsen NJ and Short T. A missense variant of the porcine melanocortin-4 receptor $(M C 4 R)$ gene is associated with fatness, growth, and feed intake traits. Mammalian Genome, 11: 131-135. 2000.

Lee YS, Poh LK and Loke KY. A novel melanocortin 3 receptor gene $(M C 3 R)$ mutation associated with severe obesity. Journal of Clinical Endocrinology and Metabolism, 87: 14231426. 2002.

Li SP, Du ZH, Ning FY, Sun HX and Bai XJ. Correlation analysis between $M C 3 R$ and $M C 4 R$ gene polymorphism and growth traits in pigeon. Hereditas, 30: 1333-1340. 2008.

Roselli-Rehfuss L, Mountjoy KG and Robbins LS. Identification of a receptor for gamma melanotropin and other proopiomelanocortin peptides in the hypothalamus and limbic system. Proceedings of the National Academy of Sciences of the United States of America, 90: 8856-8860. 1993.

Rosmond R, Chagnon M and Bouchard C. A missense mutation in the human melanocortin-4 receptor gene in relation to abdominal obesity and salivary cortisol. Diabetologia, 44 (10): 1335-1338. 2001.

Santoro N, Perrone L, Cirillo G, Raimondo P, Amato A, Brienza $\mathrm{C}$ and Giudice EM. Effect of the melanocortin-3 receptor $\mathrm{C}$ 17A and G241A variants on weight loss in childhood obesity. American Journal of Clinical Nutrition, 85: 950-953. 2007.

Schwartz MW, Woods SC, Porte DJ, Seeley RJ and Baskin DG. Central nervous system control of food intake. Nature, 404: 661-671. 2000.

Stephens JC, Schneider JAD, Tanguay A, Choi J, Acharya T, Stanley SE, Jiang R, Messer CJ, Chew A, Han JH, Duan J, Carr JL, Lee MS, Koshy B, Kumar AM, Zhang G, Newell WR, Windemuth A, Xu C, Kalbfleisch TS, Shaner SL, Arnold K, Schulz V, Drysdale CM, Nandabalan K, Judson RS, Ruano G. and Vovis GF. Haplotype variations and linkage disequilibrium in 313 human genes. Science, 293: 489-493. 2000.

Takeuchi S and Takahashi S. Melanocortin receptor genes in the chicken-Tissue distributions. General and Comparative Endocrinology, 112: 220-231. 1998.

Takeuchi S and Takahashi S. A possible involvement of melanocortin 3 receptor in the regulation of adrenal gland function in the chicken. Biochim Biophys Acta, 1448: 512518. 1999.

Yeo GS, Farooqi IS, Aminian S, Halsall DJ, Stanhope RG and O'Rahilly S. A frameshift mutation in $M C 4 R$ associated with dominantly inherited human obesity. Nature Genetics, 20: 111-112. 1998.

Vaisse GS, Farooqi IS, Aminian S, Halsall DJ, Stanhope RG and O'Rahilly S. A frameshift mutation in human $M C 4 R$ is associated with a dominant form of obesity. Nature Genetics, 20: 113-114. 1998.

Walker JM, Akil H and Watson SJ. Evidence for homologous actions of pro-opiocortin products. Science, 210: 1247-1249. 1980.

Zhang WH, Collins A and Morton NE. Does haplotype diversity predict power for association mapping of disease susceptibility. Human Genetics, 115: 157-16. 2004. 